\title{
EFFECTS OF STORAGE AND SULFURIZATION WITH SULFUR DIOXIDE OF DIFFERENT CONCENTRATION ON CHANGES IN THE COLOR OF DRIED APRICOTS
}

\author{
UTICAJ SUMPORISANJU PRIMENOM RAZLIČITIH \\ KONCENTRACIJA SUMPORA I SKLADIŠTENJA NA \\ PROMENU BOJE KAJSIJE
}

\author{
Krstan KEŠELJ, Mirko BABIĆ, Ivan PAVKOV, Milivoj RADOJČIN, Zoran STAMENKOVIĆ, Dragana TEKIĆ, Mladen IVANIŠEVIĆ \\ University of Novi Sad, Faculty of Agriculture, Trg Dositeja Obradovića 8, 21000 Novi Sad, Serbia \\ e-mail:krstan.keselj@polj.uns.ac.rs
}

\begin{abstract}
The purpose of this paper is to examine the effects of storage and treatment with sulfur dioxide of different concentration on the overall change in the color of dried apricots. Upon sulfurization of the prepared apricot samples, they were dried using the combined osmotic-convective drying technology, and subsequently kept either in a storage unit at $t \approx 25{ }^{\circ} \mathrm{C}$ or in a cooled environment at $t \approx 3$ ${ }^{\circ} \mathrm{C}$ over a period of six months. The sample color was measured on the inside and the outside of the dried apricot fruits. Statistical analysis was performed using the Dependent Samples T-test so as to determine changes in the color of dried apricots after 3 and 6 months of storage. After six months of storage, the smallest color change of $\Delta E=6.56$ was measured in the apricot samples stored in a cooled environment. After six months, the greatest color change of $\Delta E=49.38$ was measured in the apricot samples stored at an air temperature of $25^{\circ} \mathrm{C}$.
\end{abstract}

Key words: apricot, color change, storage, drying, sulfurization.

\section{REZIME}

Tokom procesa sušenja potrebno je očuvati fizičke, hemijske i organoleptičke osobine materijala koji se suši. Boja, kao fizička osobina poljoprivrednih materijala, sklona je promenama tokom sušenja i skladištenja. Cilj rada je da se ispita uticaj tretiranja kajsije sumpor dioksidom različitih koncentracija, vreme skladištenja i temperaturu skladištenja osušene kajsije na ukupnu promenu boje kajsije. Tehnološki postupak sumporisanja pripremljene kajsije za sušenje izveden je sagorevanjem, tehničkog sumpora $i$ držanjem pripremljene kajsije u atmosferi zasićenoj sumpor dioksidom u trajanju od dva sata u komori za sumporisanje. Masa sagorevanog sumpora je: 0,40, 0,50, 0,55, 0,65, i 0,75 g po $1 \mathrm{~kg}$ pripremljenog voća. Nakon sumporisanja, kajsija je osušena kombinovanom tehnologijom osmotsko-konvektivnog sušenja i potom skladištena u polipropilen kutijama, u okruženju sobne temperature vazduha $\left(t \approx 25^{\circ} \mathrm{C}\right)$ i u rashlađenom okruženju $\left(t \approx 3^{\circ} \mathrm{C}\right)$ u vremenskom intervalu od šest meseci. Osmotsko sušenje izvedeno u fruktozno-glukoznom sirupu pri koncentraciji od $60^{\circ} \mathrm{Bx}$ i temperature rastvora od $40^{\circ} \mathrm{C}$ u trajanju od jednog sata. Konvektivno sušenje izvedeno je pri brzini vazduha za sušenje od $1 \mathrm{~m} / \mathrm{s}$ ispred sloja materijala i temperaturi vazduha od $60^{\circ} \mathrm{C}$, $u$ trajanju od 20 sati. Tokom skladištenja, uzorci su bili zaštićeni od svetlosti, vlage $i$ hermetički zatvoreni. Boja je merena sa unutrašnje (eksokarp) i spoljašnje strane (mesokarp) osušenog voća. Nakon šest meseci, najmanja promena boje od $\Delta E=6,56$, izmerena je na spoljnim stranama uzoraka kajsije tretirane sumpor dioksidom sagorevanjem od $0,75 \mathrm{~g}_{\mathrm{s}} / \mathrm{kg}_{\text {voća }}$, pri skladištenju $\mathrm{u}$ rashlađenoj atmosferi. Nakon šest meseci, najveća promena boje od $\Delta E=49,38$, izmerena je na unutrašnjim stranama uzoraka kajsije tretirane sumpor dioksidom sagorevanjem od $0,50 \mathrm{~g}_{s} / \mathrm{kg}_{\text {voća }}$, pri skladištenju u okruženju sobne temperature. Primenjene koncentracije sumpora od 0,4 - 0,75 $\mathrm{g}_{\mathrm{s}} \mathrm{kg}_{\text {voća, }}$ u postupku sumporisanja, ne dovode do značajnih razlika u promeni boje, kako spoljašnje tako i unutrašnje.

Ključne reči: kajsija, promena boje, skladištenje, sušenje, sumporisanje.

\section{INTRODUCTION}

Serbia is one of the leading apricot producers in the region, with an average production of 29,011 tons in the period 20102017 (FAO, 2019). Apricots are mostly marketed fresh in Serbia, resulting in their relatively low selling prices. However, higher selling prices of apricots could be achieved by processing, storing, drying or some other type of preserving. Turkey, as the leading apricot producer worldwide (with a production of 660,000 tons of fresh apricots in 2009), exported 96,876 tons of dried apricots in 2009, generating a revenue of 276.2 million US dollars (Kadir Ozturk, 2011). This is a good example of achieving higher revenues by using appropriate types of food processing. One of the essential sensory properties of fresh and processed food is its appearance (Costa et al., 2011), i.e. the size, shape, texture, mass, shine, color and other food properties. However, the quality of food is not a well-defined feature as it includes a number of product characteristics. The color of the product can be used to determine its pigment content, which represents one of the food quality indicators (Radojčin, 2015). The first quality parameter that a consumer estimates when buying fresh or dried fruit is color, which crucially affects the customer's decision to purchase fruit (Leon et al., 2006). The sulfur dioxide process prevents non-enzymatic browning (Tepić, 2012). Sulfurization is performed before the drying process in order to preserve the color of apricots. Consequently, the color of dried apricots remains stable over longer periods of time. The permitted sulfur content of dried fruit is stipulated by legal rules and regulations. 
The purpose of this paper is to determine changes in the color of apricots after combined drying and under different storage conditions (namely different storage temperatures and times). Moreover, the minimum amount of sulfur for combustion was determined for obtaining the desired color of dried apricots. The sample apricots were treated with sulfur dioxide of different concentration. During storage, the content of adsorbed sulfur gradually decreases depending on the storage conditions (Kadir Ozturk, 2011). In addition to the use of sulfur dioxide, the rate of non-enzymatic darkening is also affected by oxygen, light, dry matter contents, storage temperatures, elevated temperatures, etc. (Tepić, 2012)

\section{MATERIAL AND METHOD}

\section{Material and sulfurization}

Apricots of the 'NS4' cultivar were used in the experiment. They were purchased from a local producer. The average moisture content of the fresh sample was $83.2 \%$, whereas the average moisture content of dried samples was $29.1 \%$. Sulfurization was performed by a dry procedure, i.e. the combustion of technical sulfur in a sulfurization chamber. The dimensions of the sulfur chamber are $2 \times 0.32 \times 0.51 \mathrm{~m}$ or 0.327 $\mathrm{m}^{3}$. The chamber was filled with $40 \mathrm{~kg}$ of apricot halves with a porosity of $40 \%$, thus leaving $0.23 \mathrm{~m}^{3}$ of free space. The sulfurization process lasted two hours. The following quantities of sulfur powder were used: $0.40,0.50,0.55,0.65$, and $0.75 \mathrm{~g}$ per kilogram of the prepared fruit. During sulfurization, each batch contained $40 \mathrm{~kg}$ of fruit. Table 1 shows the concentration of sulfur in the sulfurization chamber. The sulfur dioxide content was determined using the volumetric method.

Table 1. Concentration of sulfur in the sulfurization chamber

\begin{tabular}{|c|c|c|}
\hline $\begin{array}{c}\text { Sulfur powder per } \\
\text { batch }\left[\mathrm{g}_{\mathrm{s}} / \mathrm{kg}_{\text {fruit }}\right]\end{array}$ & $\begin{array}{c}\text { Sulfur concentration } \\
{\left[\mathrm{kg}_{\mathrm{s}} / \mathrm{kg}_{\text {air }}\right]}\end{array}$ & $\begin{array}{c}\text { Sulfur } \\
{[\mathrm{PPM}]}\end{array}$ \\
\hline 0.40 & 0.057 & 57000 \\
\hline 0.50 & 0.072 & 72000 \\
\hline 0.55 & 0.079 & 79000 \\
\hline 0.65 & 0.0938 & 93800 \\
\hline 0.75 & 0.108 & 108000 \\
\hline
\end{tabular}

The apricot fruits were cut into halves, and the average length (a), width (b) and thickness (c) of the haves were measured, as well as the average mass. These values were measured using a total of ten samples (Table 2).

Table 2. Mean values of apricot halves

\begin{tabular}{|c|c|c|c|c||}
\hline \hline & $\begin{array}{c}\text { Lenght a } \\
\mathrm{mm}]\end{array}$ & $\begin{array}{c}\text { Width } \\
\mathrm{b}[\mathrm{mm}]\end{array}$ & $\begin{array}{c}\text { Thickness } \\
\mathrm{c}[\mathrm{mm}]\end{array}$ & $\begin{array}{c}\text { Mass } \\
\mathrm{m}[\mathrm{g}]\end{array}$ \\
\hline $\bar{X}$ & 56.75 & 54.24 & 48.34 & 77.1 \\
\hline
\end{tabular}

\section{Drying process and storage}

Osmotic drying was performed at a concentration of osmotic fructose-glucose syrup of $60{ }^{\circ} \mathrm{Bx}$ and a solution temperature of $40{ }^{\circ} \mathrm{C}$ for one hour. The addition of sucrose may in some cases prevent or reduce non-enzymatic browning (Milić et al., 1988). Convective drying was carried out at an air velocity of $1 \mathrm{~m} / \mathrm{s}$ and an air temperature of $60{ }^{\circ} \mathrm{C}$ for 20 hours. The average moisture content after drying was $29.1 \%$. After drying, 30 samples were randomly selected for a treatment with each sulfur concentration under consideration. A total of 30 samples were allocated to two sets of 15 each: one set was stored at an air temperature of $t \approx 25$ ${ }^{\circ} \mathrm{C}$, whereas the other at an air temperature $\mathrm{t} \approx 3{ }^{\circ} \mathrm{C}$. During storage, all the samples were protected from sunlight and hermetically sealed in polypropylene boxes.

\section{Color change}

The color of the samples was measured using the Konica Minolta CR400 colorimeter immediately after convective drying, and after three and after six months of storage. The color was measured on the inside (mesocarp) and on the outside (exocarp) of the dried fruit. The color change measurements were performed according to the CIELAB coordinate (L, a, b) color system. The parameter "a" includes positive values for red and negative values for green. The parameter " $b$ " includes positive values for yellow and negative values for blue. The "L" parameter defines the brightness and is located on the vertical axis. This parameter has a range from black to white (Radojčin, 2010). Therefore, the total color change $\Delta \mathrm{E}$ was determined according to the following equation:

$$
\Delta \mathrm{E}=\sqrt{\Delta \mathrm{a}^{2}+\Delta \mathrm{b}^{2}+\Delta \mathrm{L}^{2}}
$$

where $\Delta \mathrm{E}$ is the total color change, and $\Delta \mathrm{a}, \Delta \mathrm{b}$ and $\Delta \mathrm{L}$ denote differences in the color parameter values.

Differences in the color parameters $\Delta \mathrm{a}, \Delta \mathrm{b}$ and $\Delta \mathrm{L}$ are the differences between the values measured immediately after drying and after three and six months of storage.

\section{Statistics}

Statistical analysis (descriptive and comparison of means) was performed using the Dependent Samples T-Test $(\mathrm{p}<0.05)$ and Statistica 13 (Stat Soft, Inc., Oklahoma, United States). The T-test of the difference between the arithmetic means of small dependent samples was performed to test the difference in apricot color change after 3 and 6 months of storage. The Duncan test was performed to determine the difference between treatment groups with a statistical significance of $\mathrm{p}<0.05$ using Statistica 13 (Stat Soft, Inc., Oklahoma, United States)

\section{RESULTS AND DISCUSSION}

Figures 2 and 3 show graphs of the total color change $\Delta \mathrm{E}$ of dried apricots after three and six months of storage at an air temperature $\mathrm{t} \approx 25^{\circ} \mathrm{C}$. Significant changes were measured after both 3 and 6 months of storage, particularly on the inside of the samples.

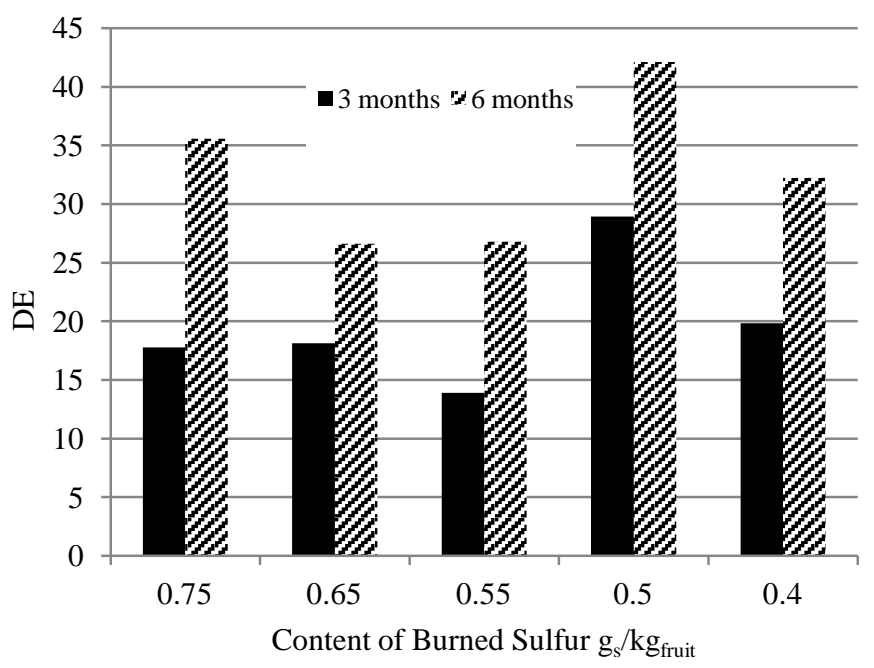

Fig. 2. Total color change measured on the outside of the samples stored at an air temperature of $t \approx 25^{\circ} \mathrm{C}$ 
After three months of storage, the greatest change in the outside color of the samples was measured in the samples treated with $0.50 \mathrm{~g}_{\mathrm{S}} / \mathrm{kg}_{\text {fruit }}(\Delta \mathrm{E}=28.9)$. After six months of storage, the greatest change in the outside color of the samples was recorded in the samples treated with $0.5 \mathrm{~g}_{\mathrm{s}} / \mathrm{kg}_{\text {fruit }}(\Delta \mathrm{E}=42.1)$ (Figure 2).

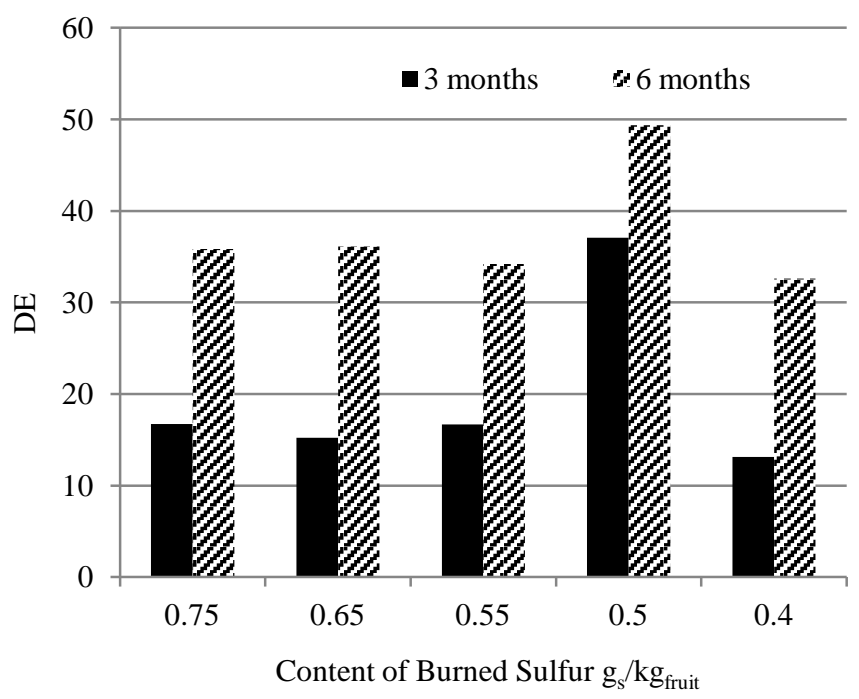

Fig. 3. Total color change measured on the inside of the samples stored at an air temperature of $t \approx 25^{\circ} \mathrm{C}$

The greatest change in the inside color of the samples after three months of storage was measured in the samples treated with $0.50 \mathrm{~g}_{\mathrm{S}} / \mathrm{kg}_{\text {fruit }}(\Delta \mathrm{E}=37.1)$. However, the greatest change in the inside color of the samples after six months of storage was measured in the samples treated with $0.50 \mathrm{~g}_{\mathrm{s}} / \mathrm{kg}_{\text {fruit }}(\Delta \mathrm{E}=49.4)$ (Figure 3). When the value of $\Delta \mathrm{E}$ is greater than 5 , the human eye perceives it as two different shades of the same color (Kowalski, et al., 2016). After three months of storage at an air temperature of $\mathrm{t} \approx 25^{\circ} \mathrm{C}$, color changes were visible to the naked eye both on the outside and the inside of the sample fruits. However, the changes were even greater and more perceivable after six months of storage.

Figures 4 and 5 show graphs of the total color change $\Delta \mathrm{E}$ after three and six months of storage at an air temperature of $t \approx$ $3{ }^{\circ} \mathrm{C}$. There were no significant changes after 3 months of storage. Similar results were obtained after six months of storage. However, the greatest changes were recorded in the inside color of the samples.

The greatest change in the outside color of the samples after three months of storage was measured in the samples treated with $0.40 \mathrm{~g}_{\mathrm{S}} / \mathrm{kg}_{\text {fruit }}(\Delta \mathrm{E}=7.41)$.

After six months of storage, the greatest change in the outside color of the samples was recorded in the samples treated with $0.50 \mathrm{~g}_{\mathrm{S}} / \mathrm{kg}_{\text {fruit }}(\Delta \mathrm{E}=12.4)$ (Figure 4).

The greatest change in the inside color of the samples after three months of storage was recorded in the samples treated with $0.40 \mathrm{~g}_{\mathrm{S}} / \mathrm{kg}_{\text {fruit }}(\Delta \mathrm{E}=9.05)$. After six months of storage, the greatest change in the inside color of the samples was measured in the samples treated with $0.75 \mathrm{~g}_{\mathrm{s}} / \mathrm{kg}_{\text {fruit }}(\Delta \mathrm{E}=13.33$ ) (Figure 3 ). Upon comparison of the results obtained for both types of storage, it is clear that treating apricots with the sulfur concentrations examined will not make significant differences in preserving the color of dried apricots after both three and six months of storage, which was also confirmed by the Duncan test results presented in Tables 3 and 4.

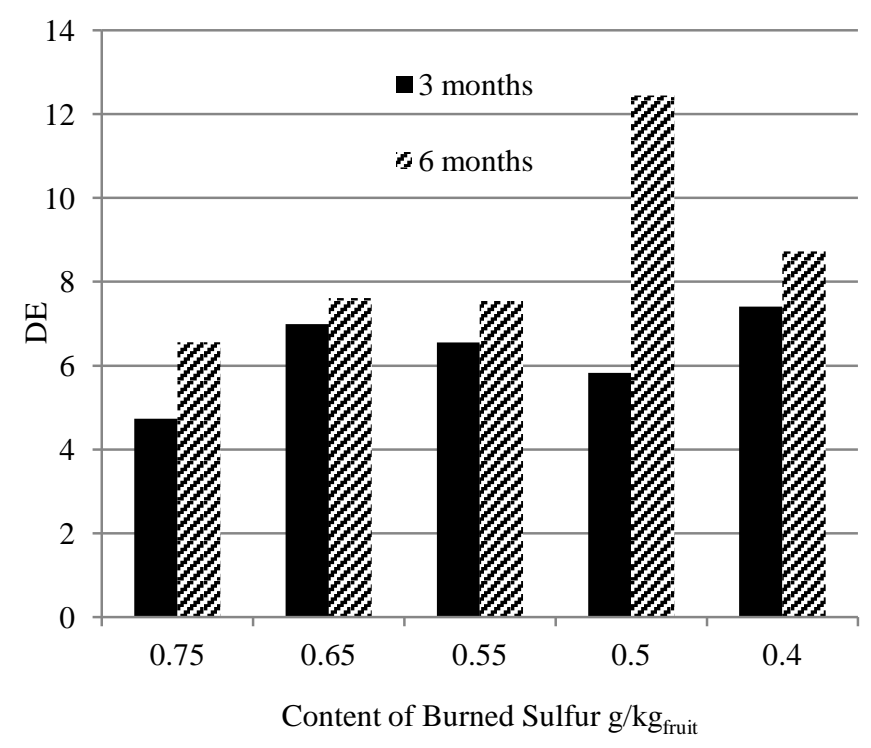

Fig. 4. Total change in the outside color of the samples stored at a an air temperature of $t \approx 3{ }^{\circ} \mathrm{C}$

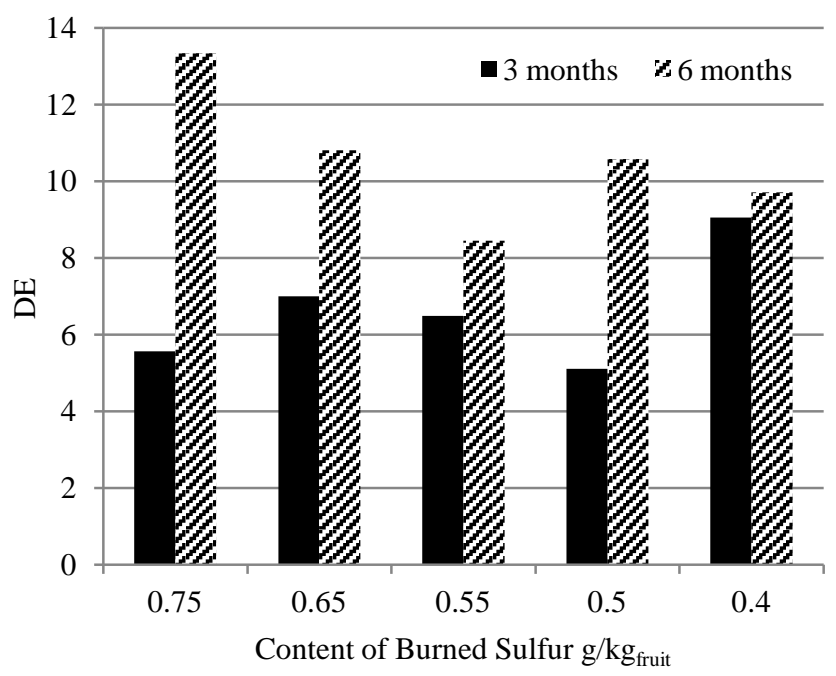

Fig. 5. Total change in the inside color of the samples stored at an air temperature of $t \approx 3{ }^{\circ} \mathrm{C}$

As shown in Table 3, there are no significant changes in the outside $\Delta \mathrm{E}$ of the apricot samples after three months of storage at a temperature of $3{ }^{\circ} \mathrm{C}$. This can be accounted for by a small overall discoloration of all the samples. Sulfur treatments do not significantly affect the sample discoloration at a storage temperature of $3{ }^{\circ} \mathrm{C}$ and a storage period of three months. After three months of storage at $25{ }^{\circ} \mathrm{C}$, a difference of $0.5 \mathrm{~g}_{\mathrm{s}} / \mathrm{kg}_{\text {fruit }}$ was observed between the two sets of samples. This difference can be explained by the content of $\mathrm{SO}_{2}$ in the fruit (Table 5). The lower $\mathrm{SO}_{2}$ content measured results in more intense browning, which explains the differences between the sample sets. According to Tepić, the use of sulfur dioxide is one of the measures for controlling non-enzymatic browning (Tepić, 2012). A similar trend was observed after six months of storage in the samples stored at a temperature of $3{ }^{\circ} \mathrm{C}$ and treated with 0.5 $\mathrm{g}_{\mathrm{so} 2} / \mathrm{kg}_{\text {fruit }}$. The samples stored at $25{ }^{\circ} \mathrm{C}$ follow a similar pattern, with the largest difference observed again in the samples treated with $0.5 \mathrm{~g}_{\mathrm{s}} / \mathrm{kg}_{\text {fruit }}$. 
Table 3. Duncan test - the outside color of the fruit samples

\begin{tabular}{|c|c|c|c|c|c|c|}
\hline \multirow{2}{*}{ SP } & \multirow{2}{*}{ ST } & \multicolumn{5}{|c|}{$\Delta \mathrm{E}$ values for the sulfur content $\left[\mathrm{g}_{\mathrm{S}} / \mathrm{kg}_{\text {fruit }}\right]$} \\
\hline & & 0.40 & 0.5 & 0.55 & 0.65 & 0.75 \\
\hline \multirow[b]{2}{*}{3} & 3 & $7.40^{\mathrm{i}}$ & $5.83^{\mathrm{i}}$ & $6.55^{\mathrm{i}}$ & $6.99^{\mathrm{i}}$ & $4.73^{\mathrm{i}}$ \\
\hline & 25 & $19.82^{\mathrm{e}}$ & $28.94^{\mathrm{dc}}$ & $13.91^{\mathrm{gf}}$ & $18.10^{\mathrm{e}}$ & $17.76^{\mathrm{fe}}$ \\
\hline \multirow{2}{*}{$\theta$} & 3 & $8.73^{\text {ih }}$ & $12.45^{\text {hg }}$ & $6.99^{i}$ & $7.62^{i}$ & $6.55^{1}$ \\
\hline & 25 & $32.23^{\mathrm{cb}}$ & $42.11^{\mathrm{a}}$ & $26.79^{\mathrm{d}}$ & $26.63^{\mathrm{d}}$ & $35.59^{b}$ \\
\hline
\end{tabular}

Different lowercase letters indicate significant differences $(p<0.05)$. SP - Storage period in months; ST - Storage temperature $\left[{ }^{\circ} \mathrm{C}\right]$

As shown in Table 4, it is clear that the Duncan test results are very similar to the results in Table 3 . The only difference is a slight increase in the change of the inside color of the fruit samples. Different fruit ripening periods are one of the reasons for different $\mathrm{SO}_{2}$ adsorption levels, confirming that sulfur dioxide is directly related to the quality of color retention.

Table 4. Duncan Test - the inside color of the fruit samples

\begin{tabular}{|c|c|c|c|c|c|c||}
\hline \multirow{2}{*}{ SP } & \multirow{2}{*}{ ST } & \multicolumn{5}{|c||}{$\Delta$ E values for the sulfur content $\left[\mathrm{g}_{\mathrm{S}} / \mathrm{kg}_{\text {fruit }}\right]$} \\
\cline { 3 - 7 } & & 0,40 & 0,5 & 0,55 & 0,65 & 0,75 \\
\hline \multirow{2}{*}{3} & 3 & $9.05^{\text {gle }}$ & $5.11^{\mathrm{i}}$ & $6.49^{\text {ihg }}$ & $7.00^{\text {ihgt }}$ & $5.56^{\text {ih }}$ \\
\cline { 2 - 7 } & 25 & $13.11^{\text {ed }}$ & $37.09^{\mathrm{b}}$ & $16.67^{\mathrm{d}}$ & $15.20^{\mathrm{d}}$ & $16.73^{\mathrm{d}}$ \\
\hline \multirow{2}{*}{6} & 3 & $9.70^{\text {hgt }}$ & $10.57^{\text {te }}$ & $8.44^{\text {higt }}$ & $10.58^{\text {fe }}$ & $13.33^{\text {ed }}$ \\
\cline { 2 - 7 } & 25 & $32.60^{\mathrm{c}}$ & $49.38^{\text {a }}$ & $34.20^{\text {cb }}$ & $36.10^{\text {cb }}$ & $35.82^{\text {cb }}$ \\
\hline
\end{tabular}

Different lowercase letters indicate significant differences $(p<0.05)$. SP - Storage period in months; ST - Storage temperature $\left[{ }^{\circ} \mathrm{C}\right]$

Table 5. Sulfur dioxide content of the fruit samples

\begin{tabular}{|c|c|}
\hline $\begin{array}{c}\text { Sulfur Burned } \\
{\left[\mathrm{g}_{\mathrm{S}} / \mathrm{kg}_{\text {fruit }}\right]}\end{array}$ & $\begin{array}{c}\mathrm{SO}_{2} \text { Content of the } \\
\text { fruit sample }[\mathrm{mg} / \mathrm{kg}]\end{array}$ \\
\hline 0.40 & 377.10 \\
\hline 0.50 & 279.83 \\
\hline 0.55 & 342.33 \\
\hline 0.65 & 491.97 \\
\hline 0.75 & 370.33 \\
\hline
\end{tabular}

Based on the parameter values obtained, it is noteworthy that the tested samples with the requirements of Article 1, Annex 2, Part D, Item 04.2.1 of the Rulebook on Food Additives of the Republic of Serbia (Official Gazette of the RS, No. 53/2018).

According to Kadir, the sulfur content of apricots decreases by $3 \%$ after one year of storage in a cooling chamber and by 34 $\%$ provided apricots are stored at ambient temperature (Kadir Ozturk, 2011). The main reason for the loss of $\mathrm{SO}_{2}$ from dried fruit is the change of $\mathrm{SO}_{2}$ into $\mathrm{SO}_{4}{ }^{-2}$ due to the oxidation process (Davis et al., 1973). By storing it appropriately, in this case at $\mathrm{t} \approx$ $3{ }^{\circ} \mathrm{C}$, the color of the product can be preserved much longer. The effect of proper storage on dried apricots is shown in Figures 6 and 7. The samples shown were photographed after six months of storage. All the samples were treated with the same amount of $\mathrm{SO}_{2}$.

Table 6. T-test values

\begin{tabular}{|c|c|c|c|c|c|c|c|c|c|c|c|c|}
\hline \multirow[t]{2}{*}{ Variable } & \multicolumn{3}{|c|}{$\begin{array}{l}\text { The outside color } \\
\text { of the samples } \\
\text { stored at an air } \\
\text { temperature of } \\
t \approx 3^{\circ} \mathrm{C}\end{array}$} & \multicolumn{3}{|c|}{$\begin{array}{l}\text { The inside color } \\
\text { of the samples } \\
\text { stored at an air } \\
\text { temperature of } \\
\quad t \approx 3^{\circ} \mathrm{C}\end{array}$} & \multicolumn{3}{|c|}{$\begin{array}{l}\text { The outside color } \\
\text { of the samples } \\
\text { stored at an air } \\
\text { temperature of } \\
\quad t \approx 25^{\circ} \mathrm{C}\end{array}$} & \multicolumn{3}{|c|}{$\begin{array}{l}\text { The inside color } \\
\text { of the samples } \\
\text { stored at an air } \\
\text { temperature of } \\
\quad t \approx 25^{\circ} \mathrm{C}\end{array}$} \\
\hline & Mean & $\mathrm{t}$ & $p$ & Mean & $\mathrm{t}$ & $p$ & Mean & $\mathrm{t}$ & $p$ & Mean & $\mathrm{t}$ & $p$ \\
\hline 3 months & 0.631 & \multirow{2}{*}{-3.34} & \multirow{2}{*}{0.028} & 1.000 & \multirow{2}{*}{-5.10} & \multirow{2}{*}{0.007} & 15.574 & \multirow{2}{*}{-15.89} & \multirow{2}{*}{0.001} & 13.526 & \multirow{2}{*}{-37.08} & \multirow{2}{*}{0.001} \\
\hline 6 months & 2.709 & & & 6.478 & & & 27.742 & & & 34.046 & & \\
\hline
\end{tabular}

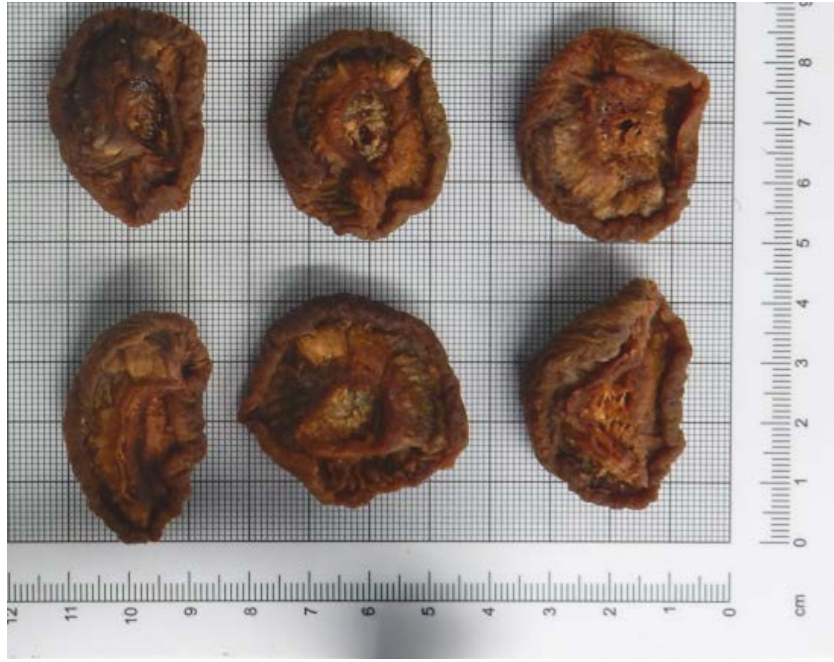

Fig. 6. Apricot treated with $0.5 g_{\mathrm{SO}_{2}} / \mathrm{kg}_{\text {fruit }}$ and stored at $t \approx 25{ }^{\circ} \mathrm{C}$ after six months of storage

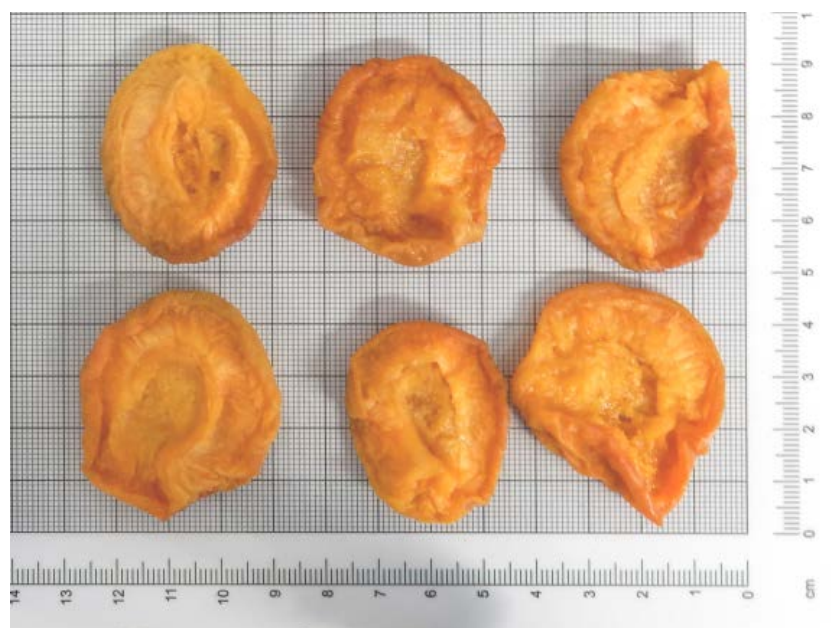

Fig. 7. Apricot treated with $0.5 g_{\mathrm{SO}_{2}} / \mathrm{kg}_{\text {fruit }}$ and stored at $t \approx 3{ }^{\circ} \mathrm{C}$ after six months of storage

A t-test was applied to determine the total sample color change. Table 5 presents the t-test values obtained for measuring the sample color change over 3 and 6 months of storage

Statistical analysis of the t-test conducted confirmed statistically significant differences between the samples after 3 and 6 months of storage. Statistically significant differences were observed in all the samples $(\mathrm{p}<0.05)$.

\section{CONCLUSION}

The sulfurization of apricot samples with sulfur of different concentration exerted no significant effects on the change in the sample color. During storage, the greatest color changes were recorded in the samples stored at an air temperature of $25^{\circ} \mathrm{C}$. Significant sample color changes occurred after 3 months of storage, and continued in a similar fashion until the end of the 6-month storage period. The color of 
the samples stored at a temperature of $3{ }^{\circ} \mathrm{C}$ did not change significantly during storage. Greater color changes were measured on the inside than on the outside of the samples stored at $25^{\circ} \mathrm{C}$. The same results were recorded in the samples stored at a temperature of $3{ }^{\circ} \mathrm{C}$. There are no significant color differences resulting from the application of different sulfur concentrations, i.e. the same results were obtained by the application of 0.4 $\mathrm{g}_{\mathrm{S}} / \mathrm{kg}_{\text {fruit }}$ and $0.75 \mathrm{~g}_{\mathrm{S}} / \mathrm{kg}_{\text {fruit. }}$. For the best sample color preservation, the application of $0.4 \mathrm{~g}_{\mathrm{s}} / \mathrm{kg}_{\text {fruit }}$ is recommended, followed by storage at an air temperature of $3{ }^{\circ} \mathrm{C}$ in dark airtight containers. The sulfur concentrations applied in the present study were quite small, thus future studies should involve the application of greater sulfur concentrations. It is also suggested that any future research should be conducted with lower moisture content values of dried fruit. The experimental samples in this study had high moisture content values, with an average value of $29.1 \%$, which also affected the speed of fruit browning.

ACKNOWLEDGEMENTS: This paper is a result of the research within the project TR31058, 2011-2020, supported by the Ministry of Education, Science and Technology of the Republic of Serbia.

\section{REFERENCE}

Babić M, Babić Ljiljana, Radojčin, M, Pavkov, I, Karadžić, B (2008): Changes in Physical Properties throughout Osmotic Drying of Quince (Cydonia oblonga mill.), Journal of proceesing and energy in agriculture, 12:3, 101-107.

Costa, C., Antonucci, F., Pallottino, F., Aguzzi, J., Sun, D., Menesatti, P. (2011). Shape analysis of agricultural products: a review of recent research advances and potential application to computer vision. Food and Bioprocess Technology, 4 (5), 673692.

Davis EG, Mcbean D, Mc G, Rooney ML, Gipps PG (1973). Mechanisms of sulphur dioxide loss from dried fruits in flexible films. J Food Technol 8:391-405.

Hadživuković, S. (1991): Statistički metodi s primenom u poljoprivrednim i biološkim istraživanjima (Drugo prošireno izdanje), Univerzitet u Novom Sadu, Poljoprivredni fakultet Novi Sad, Srbija
Kadir O., Ramazan K., Bulent O., Salih A., Belgin C., Makbule Y., Mehmet Naim D., Sezai E., (2011). Effects of Sulphurization Duration of Doses and Cold Storage on SO2 Content of Dried Apricot Fruits of cv. 'Hacihaliloglu. Not Bot Horti Agrobo, 39(2), 237-241.

Karabuluta, I., Topcub, A., Durana, A., Turanb, S., Ozturkc, B. (2007). Effect of hot air drying and sun drying on color values and b-carotene content of apricot (Prunus armenica L.). LWT, 40, 753-758

Kowalski, J.S., Pawłowski, A., Szadzińska, J., Łechtańska, J., Stasiak, M. (2016). High power airborne ultrasound assist in combined drying of raspberries. Innovative Food Science and Emerging Technologies, 34, 225-233.

Leon, K., Mery, D., Pedreschi, F., Leon, J. (2006). Color measurement in $\mathrm{L}^{*} \mathrm{a} * \mathrm{~b} *$ units from RGB digital images. Food Research International, 39 (10), 1084-1091.

Maletić, R. (2005): Metodi statističke analize u poljoprivrednim i biološkim istraživanjima (Prvo izdanje), Univerzitet u Beogradu, Poljoprivredni fakultet Beograd, Srbija

Milić Lj.B., Carić Đ.M., Vujičić L.B. (1988): Reakcija neenzimskog tamnjenja prehrambenih proizvoda. Naučna knjiga, Beograd.

Mutavdžić B., Djorić-Nikolić E. (2018): Statistika ( za smer veterinarska medicina), Univerzitet u Novom Sadu, Poljoprivredni fakultet Novi Sad, Srbija

Petz, B. (1997): Osnovne statističke metode za matematičare (VI izdanje), Naklada slap, Jastrebarsko, Hrvatska

Radojčin M. (2015): Uticaj osmotskog i konvektivnog sušenja na fizičke osobine dunje (cydonia oblonga Mill.) Phd dissertation.

Radojčin M., Babić M., Babić Lj., Pavkov I., (2011). Promena boje dunje tokom kombinovanog sušenja. Journal on Processing and Energy in Agriculture, 1821-4487 14; 2; p.8184.

Tepić A., (2012): Bojene materije voća i povrća. Univerzitet u Novom Sadu, Tehnološki fakultet.

Web pages:

http://www.fao.org

Received: 28. 11. 2019.

Accepted: 09. 12. 2019. 